\title{
NASIONALISME, NEGARA-BANGSA, DAN INTEGRASI NASIONAL INDONESIA: MASIH PERLUKAH?
}

\author{
Singgih Tri Sulistiyono \\ Departemen Sejarah Fakultas Ilmu Budaya \\ Universitas Diponegoro
}

Alamat korespondensi: singgihtrisulistiyono@undip.ac.id

Diterima/ Received: 8 Maret 2018; Disetujui/ Accepted: 30 Maret 2018

\begin{abstract}
This article based on small and trivial statements but actually has a very basic content that is often raised by some of the younger generations about the lack of importance of nationalism, nation-state and national integration of Indonesia. Perhaps such a statement is a reflection of the mood of thinking and taste of the young generation who are the mile-generation immersed in the euphoria of globalization and the advances in technology and communications and information that make the world like a village, often referred to as a 'global village'. Depart from that reality, this article aims to reflect the understanding of nationalism, nation-state, and national integration, utilizing previous studies conducted by the experts.
\end{abstract}

Keywords: Nationalism; Nation-state; National Integration.

\begin{abstract}
Abstrak
Artikel ini berangkat dari pernyataan kecil dan remeh namun sesungguhnya memiliki muatan yang sangat mendasar yang seringkali dilontarkan oleh sebagian kalangan generasi muda tentang tidak pentingnya lagi nasionalisme, negara-bangsa (nation-state), dan integrasi nasional Indonesia. Barangkali pernyataan seperti itu merupakan refleksi dari suasana berpikir dan berasa dari generasi muda yang merupakan generasi milea yang tenggelam dalam euforia globalisasi dan berbagai kemajuan di bidang teknologi dan komunikasi dan infomasi yang membuat dunia seperti sebuah desa, atau sering disebut sebagai 'desa global'. Bertolak dari realitas itu, artikel ini bertujuan untuk merefleksikan kembali nasionalisme, negara bangsa, dan integrasi nasional, dengan memanfaatkan kajian-kajian yang dilakukan oleh para ahli.
\end{abstract}

Kata Kunci: Nasionalisme; Negara-bangsa; Integrasi Nasional.

\section{PENDAHULUAN}

Globalisasi dan perkembangan teknologi informasi dan komunikasi telah mengaburkan batas-batas negara, politik, ekonomi, dan budaya. Hubungan internasional bukan hanya terbatas pada hubungan government to government (atau antarbangsa) secara formal, namun juga sudah mencakup antarkomunitas dan bahkan juga mencakup interelasi antarkomunitas atau pun antar individu secara face to face. Kemudahan interaksi global telah membangkitkan kesan bahwa keberadaan negara hanya dirasakan sebagai barier atau handycap dalam berbagai hal baik dalam ekonomi, sosial-budaya, kebebasan, hubungan internasional, dan sebagainya. Mereka membayangkan jika tidak ada negara maka akan lebih leluasa untuk mengekspresikan dirinya. Dalam konteks inilah barangkali sebagian generasi muda berpendapat bahwa negarabangsa dan integrasi nasional tidak diperlukan lagi. 
Apa yang kemudian menjadi pertanyaan adalah apakah nasionalisme, negara-bangsa, dan integrasi nasional Indonesia tidak diperlukan lagi? Untuk menjawab pertanyaan itu diperlukan kajian terhadap paling tidak dua aspek penting, yaitu aspek historis dan aspek strategis. Aspek yang pertama mengacu kepada analisis diakronis terhadap proses formasi negara-bangsa Indonesia dan intergrasi nasional Indonesia sebagai proses historis yang evolusioner. Sementara itu, aspek ke dua menyangkut kajian lingkungan strategis yang kontekstual terhadap situasi kontemporer dan bahkan prediksi masa depan.

\section{ARAS KONSEP}

Bagian ini mengulas secara singkat kaitan antara paham nasionalisme, negara bangsa, dan integrasi nasional di Indonesia. Dalam hal ini, nasionalisme sering disebut juga paham kebangsaan yang secara sederhana dapat diartikan sebagai suatu atau ideologi yang menekankan kepada para pengikutnya untuk mencintai bangsanya. Lantas, apa definisi bangsa? Seorang teoritikus dari Perancis yang bernama Ernest Renan mendefinisikan bangsa sebagai sekelompok orang yang percaya bahwa mereka merupakan sebuah bangsa (a nation is a group of people who believe themselves to be a nation). Ini merupakan definisi yang subjektif dan kontekstual serta lebih luwes. Oleh sebab itu, Bung karno sering mensitir pendapat ini untuk menjelaskan dan membangkitkan semangat kebangsaan Indonesia pada masa pergerakan nasional.

Memang harus diakui bahwa pengelompokan manusia ke dalam sistem pengelompokan yang disebut sebagai 'bangsa' bukan merupakan sesuatu yang alamiah. Pada masa awal keberadaan manusia yang merupakan keturunan homo sapien, keberadaan manusia terbagi-bagi ke dalam kelompok-kelompok suku bangsa dengan skala kecil. Pengelompokan mereka didasari atas kepercayaan bahwa mereka berasal dari keturunan yang sama (faktor genealogi). Pada masa pergerakan nasional, kampanye bahwa apa yang disebut sebagai 'bangsa Indonesia' memiliki keturunan yang sama yaitu rumpun bangsa Austronesia menghadapi problema ketika pemerintah Indonesia pascakemerdekaan berjuang untuk memasukkan berbagai suku bangsa yang tinggal di Irian Barat sebagai bagian dari bangsa Indonesia. Ternyata secara antropologis mereka memiliki nenek moyang yang berbeda yaitu rumpun bangsa PapuaMelanesia. Sekali lagi dalam hal ini definisi Renan tentang bangsa sangat cocok untuk menjadi dalih guna memasukkan suku-suku bangsa yang mendiami pulau Papua Barat menjadi bagian dari bangsa Indonesia sepanjang mereka memiliki keinginan atau merasa bahwa mereka merupakan bagian dari bangsa Indonesia.

Sebuah definisi bangsa yang lebih aktual dan kontekstual serta menghargai proses sejarah telah dirumuskan oleh Anthony Birch. Ia mendefinikan bangsa sebagai a society which either governs itself today, or has done so in the past, or has a credible claim to do so in the nottoo-distant future (sebuah masyarakat yang pada saat ini mengatur dirinya (atau dalam konteks zaman modern 'berpemerintahan sendiri'), atau telah melakukannya di masa lalu, atau memiliki klaim yang kredibel untuk melakukannya di masa depan yang tidak terlalu lama (Birch, 1989). Definisi ini memberikan kemungkinan kepada pemerintahan negara-bangsa untuk mempertahankan keutuhan bangsa mereka. Apalagi jika kinerja pemerintahan mereka mampu mempertahankan dan bahkan menumbuhkan perasaan atau keinginan untuk mencintai dan tetap menjadi bagian yang inheren dari bangsa itu, misalnya dengan telah terciptanya kemakmuran dan kesejahteraan, keadilan, kemajuan, dan sebagainya.

Di samping itu, nasionalisme juga dipahami sebagai identitas bangsa yang salah satunya harus berdasar pada kesamaan wilayah teritorial. Sejak gelombang anti-kolonial melanda, turut mendukung adanya penguatan definisi teritorial kebangsaan. Dalam setiap kasus klaim atas batas-batas kolonial secara sewenangwenang ditetapkan secara sepihak dan bukan berdasar pada etnokultural. Mereka harus bersandar pada gagasan sipil bahwa semua orang yang tinggal pada wilayah perbatasan adalah anggota bangsa yang setara. Negara-negara kepulauan seperti Indonesia tampaknya lebih cocok menganut paham nasionalisme teritorial 
dengan alasan batas-batas yang tampaknya dibatasi oleh alam, bukan oleh takdir yang ambivalen (Reid, 2001: 296). Namun demikian, yang dimaksud sebagai identitas bersama itu selalu berurusan dengan rangkaian simbol sentral (nama, bahasa, mitos-mitos sejarah, pakaian, dan gaya nasional).

Nasionalisme Indonesia menggambarkan ikatan budaya yang menyatukan dan mengikat rakyat Indonesia yang majemuk menjadi satu bangsa dalam ikatan negara-bangsa (nation state). Dalam upaya menyatukan pada sebuah ikatan itu, maka diperlukan ikatan budaya sebagai pendorong hidup bangsa. Berkembangnya nasionalisme Indonseia sangat bergantung pada kohesivitas dalam bentuk ketahanan budaya yang bertumpu pada ikatan budaya tersebut. Ikatan ini mampu menjadi daya tahan yang kuat dalam menghadapi arus globalisasi yang cenderung berdampak pada peniadaan batas-batas teritorial dan kedaulatan bangsa (Thung Ju Lan \& Manan, 2011: 5-6).

Dalam konteks keindonesiaan, perkembangan rasa kebangsaan lebih dulu berkembang daripada rasa kenusaan. Rasa kebangsaan yang muncul dalam masyarakat Indonesia dipicu oleh formasi masyarakat kolonial yang bersifat rasial. Seperti diketahui bahwa periode munculnya pergerakan nasional bersamaan dengan puncak perkembangan masyarakat kolonial yang merupakan produk dari kolonialisme Belanda di Indonesia. Dalam masyarakat kolonial itu posisi dan peranan masyarakat Indonesia dipinggirkan oleh kaum kolonialis. Dengan berbagai cara, kaum kolonialis menguasai kehidupan masyarakat Indonesia: intimidasi, mengadu domba, hingga invasi dan aneksasi. Bahkan kekuatan kolonial berusaha melanggengkan perampasan itu dengan menciptakan tata hukum yang mereka buat, sehingga seolah-olah kehadiran mereka memiliki dasar legalitas. Dengan cara begitu, mereka mencoba untuk menciptakan masyarakat kolonial dengan semangat apartheid. Basis rasial digunakan untuk menciptakan hukum-hukum kolonial. Dalam Pasal 109 Peraturan Pemerintah (Regeering Reglement) 1854 misalnya, ditetapkan adanya pembedaan golongan masyarakat: golongan Eropa dan orang-orang yang dipersamakan dengan Eropa di satu pihak, dan Pribumi di pihak lain. Pada awalnya kategori Pribumi juga mencakup orang-orang pendatang dari Asia seperti orang Cina, India, Arab, dan sebagainya. Namun, kemudian mereka dipisahkan menjadi kelompok sendiri dengan sebutan golongan Timur Asing yang menduduki kelas ke dua setelah golongan Eropa. Jadi kriteria etnik dan ras dijadikan dasar dari struktur hukum masyarakat kolonial (Houben dalam Dick, 2002). Jadi pada waktu itu masyarakat Indonesia memang sedang menghadapi ketidakadilan struktural yang sengaja diciptakan oleh penguasa kolonial yang menempatkan rakyat pribumi pada posisi yang paling hina dalam struktur masyarakat kolonial. Secara kultural, kebijakan semacam ini telah menjadikan rakyat pribumi mengidap minder-wardigheidscomplex, semacam sindrom rendah diri yang kronis.

Dalam masyarakat kolonial tersebut, batasbatas sosial ditetapkan dengan tegas antara golongan penjajah sebagai penguasa (ruller) dengan golongan terjajah (rulled), atau antara golongan Eropa (Europeanen) dan golongan Pribumi (Inlanders). Memang ada golongan Timur Asing (Vreemde Oosterlingen) namun sebagian besar dari mereka lebih condong berpihak kepada penjajah daripada kepada inlanders sebab mereka merupakan kelas sosial yang diuntungkan dalam sistem seperti itu. Dengan demikian, ingroup dan outgroup feeling yang membedakan atau bahkan mempertentangkan antara kaum terjajah dengan kaum penjajah tumbuh dengan pesat. Hal ini menjadi dasar yang kuat rasa kebangsaan atau nasionalisme di kalangan kaum pribumi. Namun demikian, ketika komitmen untuk menjadi suatu bangsa, yaitu bangsa Indonesia terbentuk, mereka belum memiliki tanah air atau nusa sebab wilayah Hindia Belanda waktu itu diklaim sebagai milik Belanda. Jadi pada waktu itu terbentuknya sebuah bangsa baru yaitu bangsa Indonesia pada waktu diikrarkan pada 28 Oktober 1928 belum memiliki wilayah negara. Mereka masih ndhompleng di wilayah yang dimiliki oleh Belanda. Mereka adalah sebuah bangsa tanpa negara (stateless nation). Barulah tahun 1945 ketika SoekarnoHatta atas nama bangsa Indonesia mempro klamasikan kemerdekaan maka bangsa Indonesia sudah memiliki negara-bangsa (nation-state) 
yaitu Republik Indonesia. Untuk selanjutnya, baru 12 tahun kemudian wilayah Negara Kesatuan Republik Indonesia (NKRI) baru diumumkan secara pasti pada tahun 1957 dengan dikeluarkannya Deklarasi Djuanda. Dengan demikian sejak 1957 bangsa Indonesia (yang diformulasikan tahun 1928 oleh para pemuda dalam Sumpah Pemuda) sudah memiliki negarabangsa (sejak 1945) dan telah memiliki wilayah negara yang definitif dengan dikeluarkannya Deklarasi Djuanda. Semangat nasionalisme Indonesia telah mendapatkan momentum untuk memberikan kesetiaan kepada bangsa, negara dan wilayah tanah air (patriotisme).

Bagaimana kaitan antara konsep nasionalisme dan negara-bangsa dengan konsep integrasi nasional? Sebagaimana yang dikemukakan oleh Birch pada awalnya pengelompokan manusia lebih didasarkan oleh kesukuan yang biasanya memiliki genealogi yang sama dan memiliki latar belakang budaya yang sama sehingga bersifat homogen. Dalam tahap perkembangan selanjut nya negara yang berbasis etnisitas (ethno-nation) muncul dan berkembang. Dalam sejarah Indonesia kerajaan-kerajaan klasik yang muncul di Nusantara sebagian besar berbasis pada etnik, seperti kerajaan Mataram, Sunda, Bone, Gowa, dan sebagainya. Oleh karena terjadi pertumbuhan penduduk dan peningkatan jaringan komunikasi dengan dunia luar, maka komunitas etnik ini kemudian berintegrasi dengan penglompokan sosial yang lebih besar. Semenjak abad ke-19 dan ke-20 mereka tergabung dalam pengelompokan yang secara populer disebut sebagai bangsa. Dalam hal ini hampir tidak ada sebuah bangsa di dunia yang betul-betul homogen dalam konteks sosiokultural. Proses transformasi yang terjadi pada dekade pertama abad kedua puluh tentang kemajuan dan moderenitas, memfasilitasi munculnya sebagai organisasi 'pribumi' moderen pertama yaitu Budi Utomo (Aspinall \& Berger, 2014: 1005). Dalam konteks ini, bangsa yang telah terbangun dan negara yang telah didirikan memerlukan sebuah proses lanjutan yaitu integrasi nasional. Birch mendefinisikan integrasi nasional sebagai "The process of combining historical communities which possessed a fairly clear sense of separate identity in the past but have been brought together by various economic, social and political developments which takes place at the national level' (Birch, 1989).

Sementara itu, Drake mendefinisikan konsep integrasi nasional mengacu kepada: the way people in different areas of a country and of different ethnic, socio-cultural and economic backgrounds feel themselves to be united and function as one nation and one identity (Drake, 1989). Sementara itu, menurut Hardstone (1976) bahwa integrasi nasional mengacu kepada: "the process of bringing together culturally and socialy discrete groups into a single territorial unit and the establishment of a national identity". Aspek historis dalam mendefinisikan konsep integrasi nasional disampaikan oleh Birch. Ia menyatakan:

"modern nations are an amalgam of historical communities which possessed a fairly clear sense of separate identity in the past but have been brought together by various economic, social and political developments. The process by which they are brought together is known as political integration, and when it takes place at the national level (as distinct from the regional or international levels) it is best described as national integration".

Dari berbagai pengertian konsep integrasi nasional tersebut dapat ditarik beberapa poin penting. Pertama, ketika formasi sebuah bangsa sudah terwujud sebagai hasil dari tumbuhnya semangat nasionalisme dan selanjutnya berhasil membentuk sebuah negara-bangsa, maka negarabangsa ini akan meminta kepada segenap warga negara-bangsa itu untuk memiliki kesetiaan. Tuntutan itu bukan saja ditujukan kepada sekelompok orang atau komunitas yang sejak awal memperjuangkan terbentuknya bangsa tersebut, tetapi juga orang-orang yang kemudian menjadi warga negara-bangsa itu. Mereka dituntut untuk memberikan kesetiaan kepada bangsa dan negara baik dalam masa-masa sulit maupun masa-masa kejayaan, diwajibkan untuk membayar pajak, mengikuti wajib militer di saat perang, mengikuti pemilihan umum dan sebagainya. Berbagai kebijakan itu merupakan bagian dari tanggung jawab negara-bangsa untuk 
mewujudkan integrasi nasional di dalam negarabangsa itu. Tanpa upaya untuk mewujudkan integrasi bangsa, maka tidak menutup kemungkinan bangsa yang semakin heterogen akan mengalami keterpecahan atau disintegrasi. Disintegrasi itu bisa bersumber baik dari dinamika internal maupun pengaruh eksternal. Demikian juga bangsa dan negara-bangsa Indonesia yang menurut konsep Ben Anderson bisa disebut sebagai imagine nation (bangsa yang dicita-citakan) bisa saja mengalami 'gagal cita' jika di dalam proses perjalanannya mengalami proses pembusukan (Anderson, 1983).

\section{LINGKUNGAN STRATEGIS- KONTEKSTUAL}

Untuk menjawab pertanyaan apakah nasionalisme, negara-bangsa, dan integrasi nasional masih diperlukan atau tidak maka perlu untuk mengkaji lingkungan strategis kontekstual yang bersifat kontemporer dan mungkin juga masih berlangsung di masa yang akan datang. Dalam konteks inilah akan terlihat dengan jelas apakah semangat nasionalisme, negara-bangsa, dan integrasi nasional masih penting untuk kehidupan sekarang atau tidak.

\section{Lingkungan Eksternal}

Pada 2009 Francis Fukuyama seorang ahli politik ekonomi Amerika Serikat (AS) menyatakan bahwa berakhirnya Perang Dingin menandai "akhir sejarah", dan "akhir dari negara-bangsa". Hal itu terkait dengan kecenderungan perjuangan ideologis global antara Blok Kiri dan Blok Kanan telah selesai dan dimenangkan oleh Blok Kanan/Barat yang merupakan kekuatan demokrasi liberal. Dalam hubungan itu, tugas politisi bukan lagi untuk memenangkan pertarungan politik dan militer, namun untuk mengelola ekonomi agar bisa memaksimalkan kemanfaatannya bagi semua (Fukuyama, 1989).

Slogan "berakhirnya negara bangsa" sempat memengaruhi cara berpikir para pemuda yang melihat globalisasi dengan segala macam kemudahan, kesenangan, dan kegemerlapannya sebagai sesuatu yang tampaknya sangat indah di mata pemuda, sedangkan negara sering kali hanya dipandang sebagai penghalang kebebasan dan hanya menarik pajak yang peruntukannya sering kali dipandang tidak jelas. Dengan demikian, sering kali kelompok 'pemuda moderen' semacam ini terhanyut dalam provokasi 'berakhirnya negara-bangsa' yang menempatkan negara-bangsa dan nasionalisme tidak penting lagi di masa kini dan mendatang.

Dalam beberapa hal Fukuyama memang benar. Namun demikian, perkembangan pascaPerang Dingin justru menunjukkan gejala lain. Memang komunisme sudah mati. Meskipun negara Republik Rakyat Cina (RRC) masih dijalankan oleh Partai Komunis, namun ini hanyalah sebuah kulit yang aneh yang berbeda dengan apa yang dikehendaki oleh Karl Marx. Di Barat, ideologi pasar bebas mencapai kemenangan yang menyusul Perang Dingin telah terbukti menjadi sesuatu yang aneh juga, karena bank-bank telah meminta campur tangan negara ketika menghadapi masalah. Hal semacam itu juga pernah menjadi kasus di Indonesia, seperti kasus Bank Century. Pasar bebas sering kali memiliki dampak destruktif yang pada akhirnya negara yang turun tangan untuk memperbaiki. Negara Inggris yang merupakan salah satu dedengkot globalisasi, pasar bebas, dan demokrasi masih saja tetap memerangi Gerakan Irlandia Utara dan mempertahankan integrasi nasional mereka. Dengan demikian dunia yang bebas ideologi yang diprediksikan oleh Fukuyama tidak jadi berlangsung. Semangat nasionalisme dan berbagai bentuk fanatisme masih terus berkembang menyusul berakhirnya perang ideologi selama periode Perang Dingin. Bisa dilihat chauvinisme Cina makin tampak dan diaspora yang mereka lakukan semakin menjadi gerakan yang sistematis. Di berbagai nagara, bukan hanya negara-negara bekas jajahan, muncul juga gerakan separatis dan keinginan untuk menjadi negara merdeka yang lepas dari ikatan sebelumnya. Demikian juga gerakangerakan mini-nationalisms-ethnic, gerakan keagamaan dan sebagainya telah muncul dan berhadap-hadapan dengan kekuatan negarabangsa yang represif (Henley, 1996).

Bahkan perkembangan mutakhir yang menimbulkan sinisme muncul dari Amerika Serikat sendiri yang dipandang sebagai 
dedengkot globalisasi dan liberalisme. Presiden ke-45 Donald John Trump dalam pidato politik perdana sebagai kepala negara dan pemerintahannya pada 20 Januari 2017 menekankan kebijakan yang bersifat protektif dan mendahulukan kepentingan nasional AS. Ia mengatakan melalui CNN bahwa:

"Kebijakan-kebijakan baru akan disampaikan di setiap kota dan negara bagian. Mulai hari ini dan seterusnya visi yang baru akan berlaku di negara kita, yaitu menempatkan Amerika sebagai yang pertama (America First). Kita akan tetap menjalin hubungan yang bersahabat dan beritikad baik dengan berbagai negara dengan tetap mendahulukan kepentingan Amerika. Ini merupakan hak setiap bangsa untuk mendahulukan kepentingan nasionalnya. Kebijakan ekonomi AS yang baru akan mengikuti dua aturan utama, yaitu membeli produk-produk dalam negeri AS (Buy American) dan mempekerjakan warga Amerika (Hire American). Kita akan membuat warga Amerika kembali bekerja dan membangun negara ini dengan tangan warga Amerika. Perlindungan akan kembali di negara ini. Amerika akan mulai berjaya lagi, berjaya lebih lagi dari sebelumnya. Kita akan membawa kembali lapangan kerja (ke dalam negeri) dan kita akan membawa kembali impian-impian kita" (http://www.antaranews.com/berita/ 608029/trump-tekankan-kebijakan-protektifas, diakses 7 November 2017).

Apa yang disampaikan oleh Trump tersebut merupakan kebijakan yang protektif untuk melindungi kepentingan bangsa dan negara mereka. Padahal kebijakan proteksi semacam itu jelas bertentangan dengan sistem perdagangan bebas yang menyerahkan geliat ekonomi pada mekanisme pasar yang meminimalkan pembatasan perdagangan oleh negara. Seperti diketahui bahwa Amerika Serikat merupakan salah satu negara utama yang sejak awal mendorong penerapan sistem perdagangan besar di dunia. Namun demikian kebijakan itu secara mengejutkan diubah ke arah yang lebih protektif ketika kepentingan negara dan bangsa mereka terusik meskipun keterusikan kepen- tingan nasional mereka bukan selalu disebabkan oleh ulah negara lain namun bisa juga disebabkan oleh kebijakan Amerika Serikat sendiri yang terlalu ekspansif dan mungkin kurang produktif. Kebijakan protektif yang diterapkan Amerika Serikat bukan saja menunjukkan sikap 'antiglobalisasi, namun juga anti-imigrasi sebagaimana Trump pernah melarang masuknya orang-orang dari tujuh negara Islam, yaitu Iran, Irak, Libia, Somalia, Sudan, Suriah dan Yaman yang dipandang sebagai sarang teroris (http://www.bbc.com/ indonesia/dunia38808189, diakses 6 November 2017). Sementara itu, proteksionisme dalam ekonomi mengacu pada kebijakan atau doktrin yang melindungi perusahaan dan pekerja di suatu negara dengan membatasi atau mengatur perdagangan luar negeri (The Economist, 28 January 2017).

Uraian di atas memberikan gambaran yang jelas bagaimana negara-negara maju yang semenjak dominasi mereka melalui kolonialisme langsung mengalami keruntuhnya menyusul Perang Dunia II meneriakkan slogan globalisasi dan pasar bebas. Kini setelah eksperimen mereka mengalami tantangan yang berat mereka mulai melakukan proteksi terhadap kepentingan nasional mereka baik kepentingan kemakmuran bangsa, negara, maupun kuutuhan entitas mereka (integrasi nasional). Dengan demikian, tampak jelas bahwa meskipun mereka meneriakkan globalisasi namun pada kenyataannya kepentingan nasional masih tetap mereka dahulukan bahkan kelihatan dengan jelas bahwa slogan globalisasi digunakan sebagai pintu masuk untuk melakukan dominasi. Demikian juga slogan pasar bebas sering kali digunakan untuk melakukan sanksi dan embargo kepada negaranegara yang mengambil sikap yang bertentangan dengan negara-negara kapitalis. Oleh sebab itu, pemikiran dan sikap untuk mengebiri dan mendistorsi eksistensi negara-bangsa Indonesia hanya karena latah globalisasi dan pasar bebas merupakan sesuatu yang menyesatkan.

\section{Lingkungan Internal}

Pentingnya semangat nasionalisme, eksistensi negara-bangsa, dan integrasi nasional dapat juga 
dilihat dari perjalanan sejarah bangsa Indonesia dan beberapa negara dunia ketiga yang merupakan bekas negara-negara jajahan. Banyak negara telah dilanda perang saudara yang menyebabkan disintegrasi negara dan bangsa karena mereka tidak mampu lagi memupuk dan mempertahankan integrasi nasional mereka, seperti Yugoslavia, Pakistan, Libanon, bahkan negara perserikatan adidaya seperti Uni-Soviet juga mengalami kehancuran. Utamanya negaranegara Dunia Ketiga seperti Indonesia yang batas-batas wilayah negara disesuaikan dengan batas-batas wilayah yang dipaksakan begitu saja oleh negara kolonial yang mewariskannya tanpa kompromi terlebih dahulu dengan penduduk setempat, maka pemupukan integrasi nasional menjadi amat penting. Selain itu, pemerintah nasional yang baru merdeka itu tidak memiliki kesempaan yang cukup untuk mengatur daerahdaerah yang dikuasainya sesuai dengan kehendak kelompok-kelompok etnik yang berbeda-beda. Dalam konteks itulah maka integrasi nasional dirasakan menjadi sesuatu yang sangat urgen. Apalagi jika negara-bangsa yang baru merdeka itu merupakan negara yang luas dan memiliki keanekaragaman potensi wilayah, ras, etnik, dan latar belakang budaya, maka integrasi nasional merupakan sesuatu yang sangat urgen. $\mathrm{Hal}$ seperti inilah yang dihadapi oleh Indonesia (Harvey, 1990; Leirissa, 1991; Syamsudin, 1985).

Ancaman disintegrasi nasional di Indonesia muncul selama Perang Kemerdekaan (1945 -1949) dan bahkan semakin menggejala pada periode segera sesudahnya. Berbagai perlawanan terhadap pemerintah pusat muncul seperti DI/TII/ PRRI/PERMESTA, RMS, Gerakan Aceh Merdeka, Gerakan Papua Merdeka, dan sebagainya. Bahkan gerakan seperatis yang disebut terakhir ini masih belum bisa diselesaikan dengan baik. Gerakan-gerakan itu merupakan gerakan yang sangat kompleks meskipun sering kali mereka menuduh pemerintah pusat terlalu mementingkan Jawa dan mengabaikan daerah-daerah luar Jawa (Ricklefs, 1981).

Dalam konteks tertentu, keutuhan bangsa Indonesia dan NKRI banyak bergantung kepada hubungan antara pusat dan daerah atau pun antara lokal dan nasional. Seperti diketahui bahwa meskipun negara Indonesia telah berdiri lebih dari tujuh dekade sejak proklamasi kemerdekaan 17 Agustus 1945, namun sebetulnya formasi dari apa yang disebut sebagai bangsa dan komunitas Indonesia masih terus dalam proses. Artinya, 'proses menjadi Indonesia' dalam konteks sosio-kultural masih terus berlangsung dan sulit diprediksikan kapan proses itu berakhir. Ben Anderson memformulasikan proses formasi komunitas dan bangsa Indonesia itu dengan konsep yang menarik, yaitu imagined community dan bahkan imagined nation (Anderson, 1983). Dengan demikian, apa yang disebut sebagai komunitas dan bangsa Indonesia merupakan sebuah masyarakat dan bangsa yang dibayangkan atau mungkin dicita-citakan yang berbeda dengan komunitas dan bangsa secara realitas.

Tentu sebuah cita-cita memerlukan proses untuk mencapainya. Pencapaian sebuah cita-cita dan tujuan akan memberikan dua kemungkinan: berhasil atau gagal. Jika berhasil, hal itu berarti ada sinkronisasi antara negara Republik Indonesia (RI) sebagai wadah dan komunitas atau pun bangsa sebagai isi. Sebaliknya, jika proses itu mengalami kegagalan maka proses pembentukan komunitas dan bangsa Indonesia itu tidak seiring dengan proses pembentukan negara RI yang pada gilirannya akan menyebabkan runtuhnya negara $\mathrm{RI}$ atau setidaktidaknya apa yang disebut sebagai negara RI tidak sama dengan seperti ketika pertama kali berdiri tahun 1945, misalnya jika Papua, Aceh, Kalimantan memisahkan diri dari negara RI.

Proses menjadi komunitas dan bangsa Indonesia (process to become Indonesian community and nation) terkait erat dengan tumbuhnya rasa keindonesiaan atau rasa menjadi bagian yang inheren dari bangsa Indonesia dan bahkan ini juga terkait erat dengan rasa memiliki (sense of belonging) di setiap anggota komunitas bangsa Indonesia. Rasa memiliki (Jawa: handarbeni) terkait dengan perasaan mencintai (Jawa: hanresnani) dan kerelaan untuk memepertahankannya (Jawa: hangrungkebi) dari segala macam tantangan yang dipandang destruktif yang akan menghancurkannya. Munculnya gerakan untuk memisahkan diri dari 
negara RI, apa pun alasannya, barangkali merupakan sebuah refleksi bagaimana 'sense of Indonesianess' masih di dalam persoalan yang serius.

Apa yang selama ini menjadi persoalan adalah bahwa fenomena resistensi daerah dan gerakan separatisme di berbagai daerah seringkali hanya dilihat dari perspektif 'pusat' yang dalam hal ini adalah pemerintah RI di Jakarta. Setiap bentuk resistensi dan separatisme dipandang sebagai manifestasi sikap tidak loyal dan pengingkaran terhadap 'konsensus luhur' dari para founding fathers yang telah merintis berdirinya negara RI. Logika kekuasaan pemerintah pusat sering kali didasari atas premis bahwa pemadaman terhadap setiap resistensi dan separatisme daerah merupakan sebuah misi untuk menegakkan 'konsensus luhur' menegakkan negara RI. Jadi setiap tindakan represif pemerintah pusat mendapatkan justifikasi dari premis berpikir seperti itu. Dalam melakukan represi, hampir tidak pernah terdengar bahwa pemerintah pusat melakukan mawas diri untuk menjawab pertanyaan mengapa resistensi dan gerakan separatisme itu terjadi. Jadi memang sudah waktunya pemerintah pusat harus konsen terhadap kemajuan daerah-daerah secara berimbang.

Disintegrasi nasional tentu saja bukan hanya selalu terkait dengan gerakan politik yang berupa separatisme. Pada awal reformasi, berbagai persoalan juga muncul terkait dengan gejala-gejala keretakan rasa keindonesiaan sebagai hasil dari konsensus kebangsaan yang telah dilakukan oleh para founding fathers. Hal itu bisa dilihat dari wacana kebudayaan nasional Indonesia yang hampir tidak pernah disinggung, sebaliknya wacana kebudayaan lokal dan etnis terus berkembang (Sulistiyono, 2009). Di beberapa daerah, revitalisasi budaya lokal dan etnik tampak sebagai upaya antitesis terhadap proses dominasi kebudayaan nasional yang didorong oleh pemerintah pusat. Mereka mulai khawatir akan kehilangan identitas lokal dan/ atau etnik, sehingga reformasi dan otonomi daerah dimanfaatkan sebagai momentum untuk merevivalisasi budaya lokal dan/etnik. Memang hal itu tidak menjadi masalah dan bahkan sebaliknya akan memperkaya kebudayaan
Indonesia. Namun demikian, yang menjadi persoalan adalah adanya upaya untuk mengembangkan budaya lokal sebagai bagian dari upaya politis untuk melepaskan diri dari bingkai NKRI.

Proses tersebut di atas dengan cepat ditunjukkan oleh berbagai kejadian yang dengan jelas mencerminkan adanya peningkatan eskalasi fanatisme etnisitas dan kelompok yang ditunjukkan dengan terjadinya konflik-konflik yang bernuansa suku bangsa, agama, ras, dan antarkelompok. Persoalan itu semakin bertambah rumit sejalan dengan berkembangnya semangat 'putra daerah' yang sering kali dijadikan kedok sebagai media untuk mengakses kekuasaan politik dan keuntungan ekonomi tanpa banyak mempertimbangkan ekses-ekses berkembangnya semangat kedaerahan dan primordialisme yang mengancam proses integrasi nasional.

Paling tidak ada dua kemungkinan untuk menangani kondisi tersebut di atas: pertama, dibiarkan secara alamiah yang memungkinkan tumbuh kembangnya kesetiaan primordial kesukuan di atas rasa kebangsaan karena kesetiaan terhadap suku bangsa merupakan sesuatu yang lebih alamiah jika dibandingkan dengan kesetiaan terhadap bangsa mengingat bahwa entintas negara-bangsa yang plural merupakan hasil sebuah rekayasa (Birch, 2009). Kedua, perlu adanya policy yang memungkinkan campur tangan negara yang bisa juga melibatkan pejabat-pejabat negara dan tokoh-tokoh masyarakat untuk ikut menentukan arah perjalanan kebudayaan bangsa di masa yang akan datang. Policy ini sering kali disamakan dengan startegi kebudayaan atau mungkin bisa disebut sebagai rekayasa kebudayaan atau cultural engineering. Hal ini terkait erat dengan kenyataan bahwa apa yang disebut sebagai kebudayaan nasional bagi Indonesia sesungguhnya masih merupakan 'imagined culture' atau sebuah bentuk kebudayaan yang dicita-citakan. Hal ini akan memperkuat integrasi negara-bangsa. Dalam konteks itulah maka sesungguhnya semangat nasionalisme, eksistensi negara-bangsa, dan proses integrasi nasional masih sangat dibutuhkan oleh bangsa Indonesia saat ini dan mungkin juga di masa mendatang. 


\section{SIMPULAN}

Dengan melihat kompleksitas persoalan yang dihadapi oleh bangsa Indonesia, baik yang bersumber dari ekspansi kekuatan eksernal maupun dinamika internal masyarakat Indonesia, maka sesungguhnya semangat nasionalisme, keberadaan negara-bangsa Indonesia, dan pemupukan integrasi nasional masih sangat dibutuhkan oleh segenap rakyat Indonesia. Negara-negara bekas kolonialis yang setelah Perang Dunia II yang meneriakkan dengan nyaring globalisasi melakukan eksperimen untuk pasar bebas jika menghadapi persoalan tetap kembali kepada otoritas negara. Negara akhirnya menjadi semacam tumbal yang digunakan untuk membayar kebobrokan yang diakibatkan oleh apa yang diyakini sebagai pasar bebas. Mungkin pasar tidak akan pernah bisa melindungi warga negara, rakyat, yang kelaparan dan tidak beruntung. Di sinilah negara yang semestinya harus diberdayakan untuk 'melindungi segenap bangsa dan seluruh tumpah darah, memajukan kesejahteraan umum dan mencerdaskan kehidupan bangsa' sebagaimana cita-cita dan konsensus luhur para founding fathers. Kenapa kita sekarang lebih mendewakan pasar bebas daripada membangun negara ini menjadi lebih baik?

\section{REFERENSI}

Anderson, B. (1983). Imagined Community: Reflections on the Origin and Spread of Nationalism. London: Verso.

Aspinall, E. \& Mark T. Berger (2010). “The Break-up of Indonesia? Nationalisms after Decolonisation and the Limits of the Nation-state in Postcold War Southeast Asia”. Third World Quarterly, Vol. 22 (6): 1003-1024.

Birch, A. H. (1989). Nationalism and National Integration. London: Unwin Hyman.

Drake, C. (1989). National Integration in Indonesia: Patterns and Policies. Honolulu: University of Hawaii Press.

Fukuyama, F. (1989). “The End of History?”. The National Interest, Summer 1989, dalam https://ps321.community.uaf.edu
/files/2012/10/Fukuyama-End-ofhistory-article.pdf, diakses 9 November 2017.

Hardstone, P. C. N. (1976). 'Nationalism and the Plural Society: Some Problems in Integration'. Singapore: Occasional paper No. 28, Institute of Humanities and Social Sciences, Nanyang University.

Harvey, D. (1990). The Condition of Postmodernity: An Enquiry into the Origins of Cultural Change. Cambridge: Blackwell.

Henley, D. (1996). Nationalism and Regionalism in a Colonial Context: Minahasa in the Dutch East Indies. Leiden: KITLV Press.

Houben, V. J. H. 'Java in the 19th Century: Consolidation of A Territorial State', dalam H. Dick (2002). The Emergence of A National Economy: An Economic History of Indonesia, 1800-2000. Leiden: KITLV Press.

"In Retreat: Global Companies in the Era of Protectionism", The Economist, 28 January 2017.

Lerissa, R. Z. (1991). PRRI, Permesta: Strategi Membangun Indonesia Tanpa Komunis. Jakarta: Pustaka Utama Grafiti.

"Mengapa Trump larang warga tujuh negara masuk ke Amerika Serikat?", http://www. bbc.com/indonesia/dunia-38808189, diakses 6 November 2017.

Reid, A. (2001). "Understanding Malay as a Source of Diverse Modern Identities." Journal of Southeast Asian Studies, Vol. 32 (3): 295-313.

Ricklefs, M.C. (1981). A History of Modern Indonesia Since ca. 1300. London: Macmillan.

Sulistiyono, Singgih T. (2009). "Historiografi Pembebasan: Suatu Alternatif”, makalah disampaikan pada Seminar Akademik dengan Tema Historiografi Indonesia Modern yang diselenggarakan oleh Jurusan Sejarah Fakultas Ilmu Budaya Universitas Gadjah Mada.

Syamsudin, N. (1985). Integrasi Nasional di Indonesia. Jakarta: Gramedia.

Thung Ju Lan, M. A. Manan (2011). Nasionalisme dan Ketahanan Budaya di 
Indonesia: Sebuah Tantangan. Jakarta: LIPI Press.

"Trump tekankan kebijakan protektif AS", http://www.antaranews.com/berita/608 029/trump-tekankan-kebijakan-protektifas, diakses 7 November 2017. 